\title{
Resource quality affects carbon cycling in deep-sea sediments
}

\author{
Daniel J Mayor ${ }^{1}$, Barry Thornton ${ }^{2}$, Steve Hay ${ }^{3}$, Alain F Zuur ${ }^{4}$, Graeme W Nicol ${ }^{5}$, \\ Jenna M McWilliam ${ }^{5}$ and Ursula FM Witte ${ }^{1}$ \\ ${ }^{1}$ Institute of Biological and Environmental Sciences, Oceanlab, University of Aberdeen, Newburgh, UK; \\ ${ }^{2}$ The James Hutton Institute, Aberdeen, UK; ${ }^{3}$ Marine Scotland Science, Scottish Government, Marine \\ Laboratory, Aberdeen, UK; ${ }^{4}$ Highland Statistics Ltd, Newburgh, UK and ${ }^{5}$ Institute of Biological and \\ Environmental Sciences, University of Aberdeen, Aberdeen, UK
}

\begin{abstract}
Deep-sea sediments cover $\sim 70 \%$ of Earth's surface and represent the largest interface between the biological and geological cycles of carbon. Diatoms and zooplankton faecal pellets naturally transport organic material from the upper ocean down to the deep seabed, but how these qualitatively different substrates affect the fate of carbon in this permanently cold environment remains unknown. We added equal quantities of ${ }^{13} \mathrm{C}$-labelled diatoms and faecal pellets to a cold water $\left(-0.7^{\circ} \mathrm{C}\right)$ sediment community retrieved from $1080 \mathrm{~m}$ in the Faroe-Shetland Channel, Northeast Atlantic, and quantified carbon mineralization and uptake by the resident bacteria and macrofauna over a 6-day period. High-quality, diatom-derived carbon was mineralized $>300 \%$ faster than that from low-quality faecal pellets, demonstrating that qualitative differences in organic matter drive major changes in the residence time of carbon at the deep seabed. Benthic bacteria dominated biological carbon processing in our experiments, yet showed no evidence of resource qualitylimited growth; they displayed lower growth efficiencies when respiring diatoms. These effects were consistent in contrasting months. We contend that respiration and growth in the resident sediment microbial communities were substrate and temperature limited, respectively. Our study has important implications for how future changes in the biochemical makeup of exported organic matter will affect the balance between mineralization and sequestration of organic carbon in the largest ecosystem on Earth.
\end{abstract}

The ISME Journal (2012) 6, 1740-1748; doi:10.1038/ismej.2012.14; published online 1 March 2012

Subject Category: geomicrobiology and microbial contributions to geochemical cycles

Keywords: bacterial growth efficiency; biogeochemistry; carbon mineralization; deep sea; resource quality; stable isotope

\section{Introduction}

A proportion of organic matter produced in the upper ocean via photosynthesis sinks down into the deep sea, carrying with it carbon from the atmosphere. Organisms inhabiting the deep seabed are the ultimate recipients of this particulate material. Any organic carbon that escapes mineralization in this environment is liable to be sequestered for millennia, ultimately representing the sequestration of atmospheric $\mathrm{CO}_{2}$ (Lampitt et al., 2008). Deep-sea sediments are estimated to bury up to $300 \mathrm{TgC}^{-1}$ globally (Burdige, 2007) and hence play a major role in the global carbon cycle (Jahnke, 1996). Understanding the factors influencing the fate of carbon at the deep seabed is necessary for discerning the

Correspondence: DJ Mayor, Institute of Biological and Environmental Sciences, Oceanlab, University of Aberdeen, Main Street, Newburgh, Aberdeenshire AB41 6AA, UK.

E-mail: dan.mayor@abdn.ac.uk

Received 16 December 2011; revised 31 January 2012; accepted 2 February 2012; published online 1 March 2012 strength of marine sediments as a global carbon sink and thus predicting how their role in climate regulation will change in the future.

The quantities of benthic (seabed) organisms and sediment community oxygen consumption (SCOC) rates in the deep sea all correlate positively with the flux of particulate organic carbon (Smith et al., 1997; Ruhl et al., 2008), suggesting that biogeochemical processes in this environment are controlled by the quantity of available resources. Nevertheless, circumstantial evidence strongly suggests that the biochemical makeup of organic material, that is, 'resource quality', also affects the structure and functioning of deep-sea benthic communities (see, for example, Wolff et al., 2011). Discrete pulses of diatoms and zooplankton faecal pellets can dominate the annual flux of organic matter to the deep seabed (Billett et al., 1983; Bathmann et al., 1987). These contrasting substrates can have similar bulk elemental stoichiometry, yet differ considerably at the biochemical level: the former are rich in labile compounds such as sugars, lipids and amino acids, whereas the latter are largely devoid of these, 
instead containing large quantities of insoluble carbohydrates (Cowie and Hedges, 1996; Mayor et al., 2011). An influx of diatom-derived organic matter to deep seabed communities initiates the rapid uptake and mineralization of carbon by the benthos (Moodley et al., 2005; Gontikaki et al., 2011b). A similar, rapid response has been proposed to occur in response to the arrival of zooplankton faecal material (Graf, 1989). Robust empirical comparisons of how the lability of organic material arriving at the deep seabed affects the fate of its constituent carbon are currently lacking.

We employed identical carbon-13 $\left({ }^{13} \mathrm{C}\right)$ tracer experiments during mid May and early October 2008 to investigate how resource quality affected carbon cycling in the bacteria-dominated sediment community found at $1080 \mathrm{~m}$ in the sub-zero waters of the Faroe Shetland Channel, Northeast Atlantic. Our aim was to examine how diatoms and copepod faecal pellets, naturally occurring substrates of contrasting qualities, influenced the rates and pathways of organic carbon cycling in this challenging environment.

\section{Materials and methods}

Production of ${ }^{13} \mathrm{C}$-labelled substrates

The techniques for producing ${ }^{13} \mathrm{C}$-labelled diatoms and faecal pellets are presented elsewhere (Mayor et al., 2011). In brief, sterile cultures of the marine diatom, Chaetoceros radicans, were grown in artificial sea water enriched with L1 medium and $\mathrm{NaH}^{13} \mathrm{CO}_{3}$ (99 atom $\%{ }^{13} \mathrm{C}$, Goss Scientific, Nantwich, UK). Concentrated diatoms were repeatedly washed with sterile filtered $(0.2 \mu \mathrm{m})$ sea water to remove dissolved inorganic and organic ${ }^{13} \mathrm{C}\left(\mathrm{DI}^{13} \mathrm{C}\right.$ and $\mathrm{DO}^{13} \mathrm{C}$, respectively). Batches of $\sim 1000$ Calanus spp. copepods were fed the labelled diatoms. The resulting faecal pellets were separated from eggs, diatoms and other debris and repeatedly washed in sterile filtered sea water. The carbon/nitrogen $(\mathrm{C} / \mathrm{N})$ ratios of the diatoms and faecal pellets were $6.3 \pm 0.2$ and $8.2 \pm 0.1$ by atoms, respectively. The C/total fatty acid ratios in these substrates, a relative measure of increasing recalcitrance, were $0.30 \pm 0.01$ and $0.83 \pm 0.05 \mu \mathrm{mol} \mathrm{C} / \mathrm{nmol}$ fatty acid, respectively.

\section{Experimental setup}

Experiments were conducted on 11 May 2008 and 01 October 2008. On both occasions, a total of 18 undisturbed sediment cores (ID $=10 \mathrm{~cm}, n=6$ per treatment) were retrieved from $1080 \mathrm{~m}$ in the Faroe Shetland Channel, Northeast Atlantic $\left(61^{\circ} 13^{\prime} 88^{\prime \prime} \mathrm{N}\right.$, $2^{\circ} 40^{\prime} 62^{\prime \prime} \mathrm{W}$; Supplementary Figure S1). The subArctic community at this location is well described (Gontikaki et al., 2011a,b) and dwells in fine- to medium-textured sediments that contain $0.3 \mathrm{wt} \%$ organic carbon. Core-warming artefacts were minimized because of the extremely cold water temperatures $\left(<2{ }^{\circ} \mathrm{C}\right.$ below $\left.450 \mathrm{~m}\right)$ and rapid transferral of cores into the experimental incubator $(\sim 15 \mathrm{~min}$ for 8 cores). The effects of decompressing sediments and their resident biota on elemental cycling are considered to be negligible when retrieved from $\leqslant 1000 \mathrm{~m}$ (Graf, 1989; Hensen et al., 2006), in part reflecting the barotolerant nature of the resident bacterial communities (Meyer-Reil and Köster, 1992). Recent ${ }^{13} \mathrm{C}$ pulse-chase experiments undertaken on communities from such depths have demonstrated that microbial and macrofaunal carbon uptake remains broadly consistent between studies conducted in situ and ex situ (Woulds et al., 2007). All cores were acclimated to the experimental conditions overnight. The equivalent of $16.7 \mathrm{mmol}$ organic carbon $\mathrm{m}^{-2}$, either in the form of diatoms or faecal pellets, was gently pipetted onto the surface of the experimental sediments $(n=6$ in both cases). This represents $\sim 10 \%$ of the annual carbon flux in this region (Schlüter et al., 2000). Treatments were randomized across corer deployments. All cores, including controls (without addition of organic matter, $n=6$ ), were topped up with bottom water, sealed with custom-made lids to prevent gas exchange and incubated at the in situ temperature $\left(-0.7^{\circ} \mathrm{C}\right)$ for 6 days. Core lids sealed against the inner surface of the core via a nitrile rubber O-ring. Gas-tight water samples from each core were collected through lid ports immediately after the introduction of organic substrates $(t=0)$ and every $24 \mathrm{~h}$ thereafter for 6 days. This was achieved by applying gentle pressure to the core lid while simultaneously drawing on the sampling syringe, thereby allowing the removal of water without the introduction of a head space beneath the core lid. Samples for the analysis of dissolved inorganic carbon (DIC and $\mathrm{DI}^{13} \mathrm{C}$ ) were sterile filtered, fixed with $0.2 \%$ (vol) $\mathrm{HgCl}$ and stored in Exetainers (Labco, Ceredigion, UK) at $4{ }^{\circ} \mathrm{C}$. Oxygen samples were transferred into $10 \mathrm{ml}$ Winkler bottles, fixed for Winkler titration and stored in the dark until analysis. Oxygen and DIC concentration data were corrected for the proportional quantities removed from the overlying waters due to sampling. At the end of the experiment, three cores from each treatment were sectioned at the following horizons and stored frozen at $-20^{\circ} \mathrm{C}$ for analysis of bacterial and archaeal community composition using PCRdenaturing gradient gel electrophoresis (PCR-DGGE) analysis of 16S rRNA gene sequences, tracer carbon incorporation into sediment bacteria phospholipid fatty acids (PLFAs) and bulk organic carbon: 0-10, $10-20,20-30,30-50$ and $50-100 \mathrm{~mm}$. The remaining three replicate cores from each treatment were sectioned at 0-20, 20-50 and 50-100 $\mathrm{mm}$ depth horizons, gently sieved $(250 \mu \mathrm{m}$ mesh $)$ and the residue preserved in $3.7 \%$ saline formaldehyde for subsequent determination of ${ }^{13} \mathrm{C}$ uptake by the constituent macrofauna. We focussed solely on the organisms inhabiting the upper $20 \mathrm{~mm}$ of sediment because tracer penetration was never apparent 
below this depth (Supplementary Figure S2) and previous work at this location has demonstrated that $95 \%$ of tracer incorporation after 6 days of incubation occurs in the upper $2 \mathrm{~cm}$ (Gontikaki et al., 2011a,b). Meiofauna $(32-250 \mu \mathrm{m})$ were not examined owing to their negligible contribution to benthic carbon processing at our experimental location $(<1 \%$ of total) (Gontikaki et al., 2011a). Concentrations of labelled $\mathrm{DO}^{13} \mathrm{C}$ introduced at the outset of the experiment were not quantified, although these have previously been shown to be $<5 \%$ of the total (Andersson et al., 2008). A schematic of the experimental setup and sampling procedure is presented in Supplementary Figure S3.

\section{Sample processing}

Oxygen concentrations were determined using an automated Winkler titration system (785 DMP Titrino, Metrohm, Runcorn, UK). DIC samples were oxidized to carbon dioxide before the concentrations and carbon isotope ratios were determined using a Gas-bench II connected to a Delta ${ }^{\text {Plus }}$ Advantage isotope ratio mass spectrometer (IRMS; both from Thermo Finnigan, Bremen, Germany). The mean amplitude of five replicate sample peaks was used to calculate DIC concentration from a calibration curve derived from an appropriate range of sodium carbonate standard solutions. Purified PLFAs extracted from freeze-dried sediment samples (White et al., 1979) were derivitized to yield fatty acid methyl esters. The concentrations and carbon isotope ratios of individual fatty acid methyl esters were measured using a GC Trace Ultra with combustion column attached via a GC Combustion III to a Delta V Advantage IRMS (all from Thermo Finnigan).

Individual PLFAs were quantified by combining the area of their mass peaks, $\mathrm{m} / \mathrm{z}=44,45$ and 46 , after background subtraction, and comparison with a known internal standard (19:0) added to each sample (Thornton et al., 2011). Bacterial carbon uptake was calculated from label incorporation into the bacterial biomarker PLFAs i15:0, ai15:0 and i16:0 (Moodley et al., 2005), assuming these represent $10 \%$ of total bacterial PLFAs and $0.056 \mathrm{gC}$ PLFA/gC biomass (Brinch-Iversen and King, 1990). Macrofauna were identified to the lowest taxonomic resolution possible (family or lower), dried, and their carbon concentrations and isotope ratios were determined using a Flash EA 1112 Series Elemental Analyser connected via a Conflo III to a Delta ${ }^{\text {Plus }} \mathrm{XP}$ IRMS (Thermo Finnigan). The bulk sediment organic carbon content and isotopic signatures were determined on decalcified samples using a Costech (Cernusco sul Naviglio, Italy) ECS 4010 elemental analyser interfaced with a Delta ${ }^{\text {Plus }}$ XP IRMS (Thermo Electron, Bremen, Germany). All calculations relating to the uptake of ${ }^{13} \mathrm{C}$ were made using well-established equations (Moodley et al., 2005) and are not repeated here for brevity. Data are expressed as the total uptake of added diatom- or faecal pellet-derived carbon $\left({ }^{12} \mathrm{C}+{ }^{13} \mathrm{C}\right)$ to account for differences in the fractional abundance of ${ }^{13} \mathrm{C}$ between the two substrates ( $49.4 \pm 0.3$ and $31.9 \pm 0.2$ atom $\%{ }^{13} \mathrm{C}$, respectively).

Microbial community structures were profiled using PCR-DGGE analysis of $16 \mathrm{~S}$ rRNA gene sequences using primers P3/P2 (Muyzer et al., 1993) for the bacterial community and a nested approach using primers A109f/Ar9r followed by rSAf/PARCH519r (Nicol et al., 2007) for the total archaeal community. Details of reagent concentrations are as described previously (Nicol et al., 2007) and thermal cycling conditions were $95^{\circ} \mathrm{C}$ for $5 \mathrm{~min}$, followed by 35 cycles of $95{ }^{\circ} \mathrm{C}$ for $30 \mathrm{~s}, 55^{\circ} \mathrm{C}$ for $30 \mathrm{~s}$ and $72{ }^{\circ} \mathrm{C}$ for $1 \mathrm{~min}$, followed by 1 cycle of $72^{\circ} \mathrm{C}$ for $10 \mathrm{~min}$ for all assays, except rSAF/PARCH5195r where the annealing temperature was $63^{\circ} \mathrm{C}$. DGGE analysis was performed using a Bio-Rad DCode Universal Mutation Detection System (Bio-Rad, Hertfordshire, UK) with gels containing $8 \%(\mathrm{w} / \mathrm{v})$ polyacrylamide and a linear gradient of $35-75 \%$ denaturant. Gels were electrophoresed in $7 \mathrm{l}$ of $1 \times$ TAE buffer at a constant temperature of $60^{\circ} \mathrm{C}$ for $900 \mathrm{~min}$ at $100 \mathrm{~V}$ and silver stained before scanning using an Epson GT9600 scanner with transparency unit (Epson Ltd, Hemel Hempstead, UK) as described previously (Nicol et al., 2007). To compare community profiles, relative (within lane) band intensities were quantified by densitometry analysis of normalized DGGE profiles using Phoretix 1-D gel analysis software (Phoretix International, Newcastle upon Tyne, UK) as previously described (Nicol et al., 2007).

\section{Estimating bacterial growth efficiency}

The contribution of meiofauna to carbon processing in the Faroe-Shetland Channel is negligible $(<1 \%$ of total) (Gontikaki et al., 2011a). Archaea typically represent $<<5 \%$ of the total prokaryotic communities found in the surficial sediments of Arctic and deep-sea environments (Sahm and Berninger, 1998; Vetriani et al., 1999; Lipp et al., 2008). We therefore assume that their metabolic response to our substrate addition experiments was also negligible, making it possible to partition the observed carbon mineralization between macrofauna and bacteria: $R_{B}=R_{T}-\left[I_{M} / N P E_{M} \times\left(1-N P E_{M}\right)\right]$, where $R_{B}$ and $R_{T}$ are the quantities of carbon mineralized over the duration of the experiment by bacteria and in total, respectively, $I_{M}$ is the quantity of added carbon incorporated into macrofaunal tissues over the duration of the experiment and $N P E_{M}$ is the net production efficiency of the macrofauna. We assume that $N P E_{M}=0.5$, although the small values of $I_{M}$ (Table 1) necessitate that estimates of bacterial growth efficiency (BGE) are insensitive to this parameter. BGE can then be estimated: $B G E=I_{B} /$ $\left(I_{B}+R_{B}\right)$, where $I_{B}$ is the quantity of added carbon incorporated in the bacterial biomass over the duration of the experiment. 
Table 1 Benthic carbon budgets for the 6-day experimental duration (mmol $\mathrm{Cm}^{-2} \exp ^{-1} \pm$ s.e.m.) in May and October

\begin{tabular}{lcc}
\hline & \multicolumn{2}{c}{ Treatment } \\
\cline { 2 - 3 } & Faecal pellet & Diatom \\
\hline May & & \\
Mineralization & $0.29 \pm 0.10(1.71)$ & $0.94 \pm 0.40(5.64)$ \\
Bacterial uptake $^{\mathrm{a}}$ & $0.47 \pm 0.25(2.79)$ & $0.70 \pm 0.13(4.20)$ \\
Macrofaunal uptake & $<0.01 \pm 0.01(0.03)$ & $0.03 \pm 0.02(0.18)$ \\
Total & $0.76 \pm 0.27(4.53)$ & $1.67 \pm 0.42(10.01)$ \\
BGE & 0.62 & 0.43 \\
& & \\
October & & $1.08 \pm 0.40(6.46)$ \\
Mineralization & $0.29 \pm 0.10(1.71)$ & $0.40 \pm 0.01(2.40)$ \\
Bacterial uptake & $0.68 \pm 0.01(4.10)$ & $0.03 \pm 0.01(0.16)$ \\
Macrofaunal uptake & $0.04 \pm 0.01(0.23)$ & 0.03 \\
Total & $1.01 \pm 0.10(6.04)$ & $1.50 \pm 0.40(9.02)$ \\
BGE & 0.73 & 0.28 \\
\end{tabular}

Abbreviation: BGE, bacterial growth efficiency.

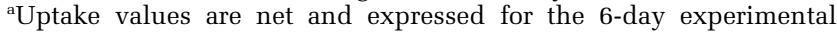
duration to avoid the assumption that rates are linear.

Values in parentheses represent the percentage of added carbon.

\section{Statistical analyses}

Initial data exploration was undertaken to identify outliers and to determine the most appropriate statistical analysis (Zuur et al., 2010). Repeated sampling of sea water from each core gave an $a$ priori reason to analyse the oxygen drawdown and carbon mineralization data sets using linear mixed-effect models (Zuur et al., 2009). This approach allowed a correlation structure (the compound symmetrical correlation) to be imposed on all observations within each core by incorporating core identity as a random effect. The protocol for model selection in linear mixed-effect modelling is described elsewhere (Zuur et al., 2009). In brief, the optimal random structure of the model was identified before the optimal fixed structure was determined. Full models with and without core identity as a random effect (random intercept) were compared using a likelihood ratio (L. ratio) test using restricted maximum likelihood estimation. The resulting $P$ values were corrected for boundary effects (Zuur et al., 2009). Variance covariate terms were also incorporated where data exploration revealed instances of unequal variance. This technique allows the residual spread to vary between individual levels of a particular explanatory variable, or combinations thereof. The significance of the random effect was reassessed after the incorporation of variance covariate terms using the L. ratio test, corrected for testing on the boundary (Zuur et al., 2009). The fixed structures of the optimal models, which initially incorporated time, treatment and month and all possible interaction terms, were determined using backwards selection based on the L. ratio test using maximum likelihood estimation. Model parameters were generated using restricted maximum likelihood estimation.
Bacterial and macrofaunal biomass-specific carbon uptake data were Box-Cox transformed before analysis to attain homogeneity of variance. Preliminary linear regression analysis of transformed data to examine the interaction between treatment $\times$ month $\times$ group ID revealed strong heterogeneity in the residual plots. Data were therefore split by month and analysed separately using linear regression. Backwards selection using the F-statistic was used to determine the optimal models.

The relative proportions of sediment PLFAs reflect the microbial community composition, and the incorporation of tracer carbon into specific PLFAs provides information on the active component of the microbial community (Boschker and Middelburg, 2002). Differences in the incorporation of added carbon into individual PLFAs between treatments and months were therefore assessed with permutational multivariate analysis of variance (perMANOVA). This test can be considered as a nonparametric analogue to multidimensional ANOVA, permitting the simultaneous response of numerous variables to be examined in an ANOVA experimental design. The tests statistics are derived from a distance (dissimilarity) matrix using permutation tests. Distance between samples was assessed using Gower's coefficient. The perMANOVA randomizations were fixed by month to account for the hierarchical sampling design. The PLFAs 14:0, 16:1w7, 16:1w5, 16:0 and all C18 s were excluded from the perMANOVA analysis because of the prevalence of these fatty acids in the diatoms and faecal pellets (Mayor et al., 2011). Additional perMANOVA analyses were used to examine month-, treatment- and month $\times$ treatment effects on the normalized DGGE profiles determined at the end of our experiments.

All statistical models were validated to check that the underlying assumptions were met. In the univariate analyses, normality of residuals was examined by plotting theoretical quantiles versus standardized residuals (Q-Q plots); homogeneity of variance was assessed by plotting residual versus fitted values; independence was verified by plotting residuals versus each covariate (Zuur et al., 2009, 2010). Homogeneity of multivariate dispersion was verified by comparing distances with spatial medians using the ANOVA F-statistic. All statistical analyses were conducted in the ' $\mathrm{R}$ ' programming environment (R Development Core Team, 2010).

\section{Results}

\section{Benthic respiration}

Mineralization rates of the introduced substrates (Figure 1) were significantly affected by resource quality (time $\times$ treatment interaction; $\mathrm{L}$. ratio $=$ 57.79, d.f. $1, P<0.001$; Supplementary Table S1), with diatom-derived carbon being respired $\sim 300 \%$ faster than that derived from faecal pellets (Table 1). 

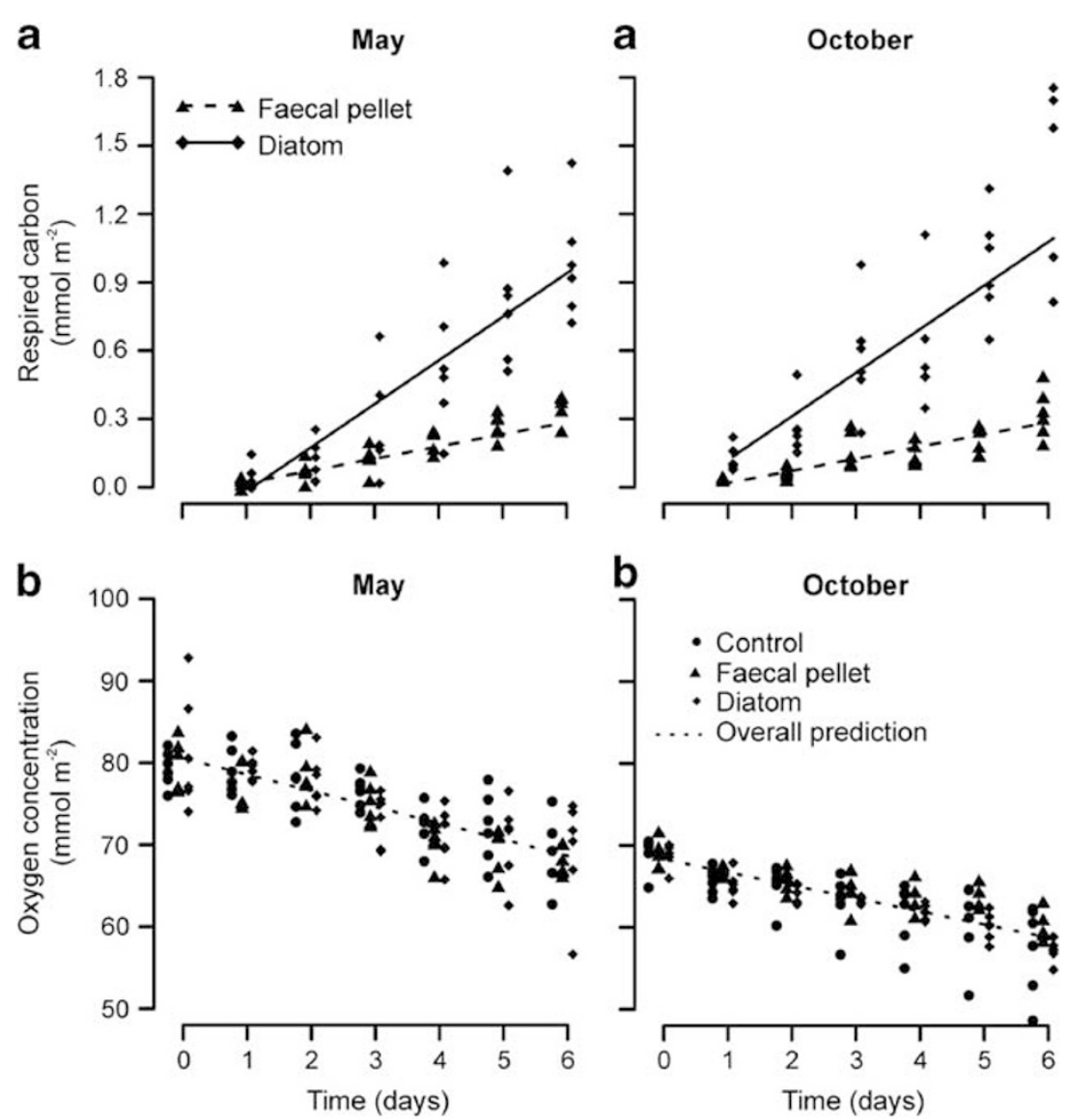

Figure 1 Food-quality effects on the rates of (a) carbon mineralization and (b) sediment community oxygen consumption in May and October.

Mineralization rates in the different treatments did not differ between months (time $\times$ treatment $\times$ month interaction; L. ratio $=2.99$, d.f. ${ }_{1}, P=0.084$ ). The time lag between substrate addition and the first appearance of $\mathrm{DI}^{13} \mathrm{C}$ in the experimental water differed by treatment and month (treatment $\times$ month interaction; L. ratio $=10.19$, d.f. ${ }_{1}, P=0.001$ ), largely reflecting a delayed response in the May diatom treatment: the intercept of this treatment was lower than those of the diatom treatment in October ( $t=3.52$, d.f.20, $P=0.002$ ) and the faecal pellet treatment in May $\left(t=-4.14\right.$, d.f. $\left.{ }_{20}, P<0.001\right)$. The SCOC rates in May and October differed significantly (time $\times$ month interaction; $\mathrm{L}$. ratio $=5.98$, d.f.,$P=0.015$; Figure 1 and Supplementary Table S2), with rates of 1.98 and $1.59 \mathrm{mmol} \mathrm{m}^{-2}$ day $^{-1}$ respectively. They were not affected by resource quality (time $\times$ treatment interaction; L. ratio $=$ 3.75, d.f. $\left.{ }_{2}, P=0.153\right)$.

\section{Organismal response}

Benthic bacteria dominated the macrofauna in terms of biomass and carbon uptake in all of our experiments (Figure 2 and Table 1). The majority of substrate-derived carbon incorporated into PLFAs occurred in the generic bacterial biomarkers i15:0,

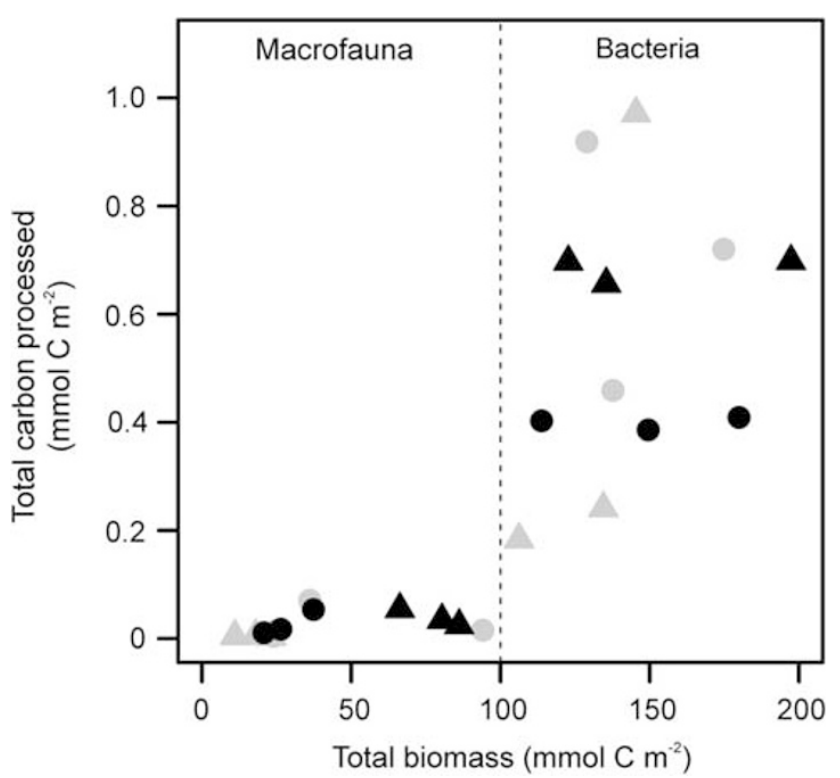

Figure 2 Benthic biomass and carbon uptake. Triangles and circles represent data from May and October, respectively; grey and black fills denote the faecal pellet and diatom treatments, respectively.

a15:0 and i16:0. Much lower and relatively uniform uptake of tracer carbon was also apparent in the PLFAs a17:0, 12 Me16:0, 17:168c, 17:0cy, 17:0, 


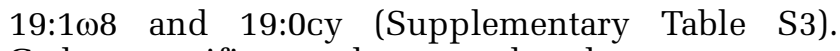
Carbon-specific uptake rates by the two groups (bacteria and macrofauna) in May were significantly different (group ID; $\mathrm{F}=26.83$, d.f. .1,10 $_{10} \quad P<0.001$; Figure 2) but treatment effects were not apparent (treatment; $F=1.13$, d.f. $._{1,9}, P=0.315$ ). A marginal treatment $\times$ group ID interaction was present in October $(\mathrm{F}=6.78$, d.f.1,8,$P=0.031)$, although subsequent examination did not reveal any significant intragroup treatment effects (Tukey's honest significant different test, $P_{\text {adj }}>0.1$ in both cases). Continued model selection demonstrated that carbon-specific uptake rates of the two groups in October were different (group ID; $F=45.80$, d.f. ${ }_{1,10}, P<0.001$ ) but not affected by treatment $\left(\mathrm{F}=0.44, \quad\right.$ d.f. $\left.{ }_{1,9}, \quad P=0.523\right)$. The distribution of added ${ }^{13} \mathrm{C}$ incorporated into the individual PLFAs was affected by a marginally significant treatment $\times$ month interaction (perMANOVA: $F=4.60$, $P=0.061$; Supplementary Table S4). In contrast, the relative compositions of the bacterial and archaeal communities at the end of our experiments (Supplementary Figure S4) were not affected by treatment, month or the interaction between these factors (perMANOVA, $\mathrm{F} \leqslant 5.78, \quad P \geqslant 0.482$ in all cases; Supplementary Table S4); they remained constant across all treatment-month combinations. Estimated values of BGE in May and October are presented in Table 1.

\section{Discussion}

Deep-sea benthic organisms, from bacteria to large metazoans, are well known to respond rapidly to pulses of organic matter (Gooday and Turley, 1990). Numerous studies have used ${ }^{13} \mathrm{C}$-labelled diatoms to quantify the rates and pathways of carbon cycling at the deep seabed (see, for example, Witte et al., 2003; Moodley et al., 2005; Woulds et al., 2007; Gontikaki et al., 2011a, b), and there is a growing appreciation that the biochemical composition of organic matter may further influence the benthic response (Wolff et al., 2011). Our study quantitatively demonstrates that resource quality exerts a profound and largely unexplored effect on the rate at which the constituent organic carbon is mineralized in permanently cold, deep-sea sediments: diatom-derived carbon was respired $>300 \%$ faster than that derived from faecal pellets. This observation is consistent with differences in carbon quality between these treatments. On the basis of $\mathrm{C} /$ total fatty acid ratios, diatoms contain $\sim 300 \%$ more labile carbon. Our data demonstrate that bulk organic carbon flux is a poor predictor of mineralization rates in this environment. Phenomenological relationships between observed bulk carbon flux and deep-sea benthic function do not, therefore, necessitate cause and effect.

Mineralization rates in the different treatments did not differ between months, illustrating that the benthic community at our experimental location is capable of rapidly capitalizing on sporadic food inputs whenever they occur, irrespective of background levels of biological activity: the SCOC rate in May was significantly greater than that in October, likely reflecting seasonal activity patterns that relate to the productivity regime and hence food supply from the overlying waters (Ruhl et al., 2008). Resource-quality effects on SCOC were not discernable, which agrees well with previous studies in which relatively small quantities of organic carbon tracers have been introduced to deep-sea benthic communities (Moodley et al., 2005; Gontikaki et al., 2011b). Indeed, the observed SCOC rates were an order of magnitude greater than would be expected from the ${ }^{13} \mathrm{C}$ mineralization data alone, illustrating that the majority of oxygen consumption was fuelled by substrates other than those introduced experimentally.

Biomass and carbon uptake in all of our experiments were dominated by bacteria, in accordance with previous ${ }^{13} \mathrm{C}$-labelled diatom addition experiments conducted on deep-sea benthic communities (see, for example, Moodley et al., 2005; Woulds et al., 2007; Gontikaki et al., 2011b). A notable exception to this pattern is the rapid macrofaunal response and retarded bacterial uptake of ${ }^{13} \mathrm{C}$-tracer observed at $4850 \mathrm{~m}$ on the Porcupine Abyssal Plane, Northeast Atlantic, using an automated lander system (Witte et al., 2003). Rather than reflecting a unique response at the Porcupine Abyssal Plane, we suggest that this apparent discrepancy reflects the relatively large quantity of diatoms $(83 \mathrm{mmol}$ organic $\mathrm{Cm}^{-2}$ ) administered in that study; macrofauna outcompete bacteria when accessing concentrated patches of organic resources and vice versa (van Nugteren et al., 2009). Contrary to our expectations, we found no evidence to suggest that substrate uptake into bacterial or macrofaunal biomass was affected by resource quality. Indeed, the observed patterns of mineralization and growth resulted in BGE being consistently lower in the diatom treatments. It is possible that treatment effects on macrofaunal growth may not have been discernable over the relatively short duration of our experiments as our methods cannot distinguish between ingested and assimilated substrates. However, the same does not hold for bacteria. Tracer incorporation into bacterial PLFAs is a highly sensitive and targeted technique for determining their rates of biosynthesis (Boschker and Middelburg, 2002); deep-sea benthic bacteria have previously been shown to incorporate diatom-derived carbon into their PLFAs within $24 \mathrm{~h}$ (Moodley et al., 2005). Treatment effects on bacterial growth, if apparent, should therefore have been readily discernable in our experiments after 6 days of incubation. A previous, 6-day study at the same experimental location documented a temporal shift from high to low BGE following the addition of diatoms. This was attributed to a switch from labile to refractory respiratory substrates as the former 
became exhausted (Gontikaki et al., 2011b). However, this interpretation is not consistent with the relatively high BGE observed in our faecal pellet treatment. Differences in BGE in our experiments could plausibly reflect the development of metabolically distinct microbial communities in the different treatments and months. Some support for this hypothesis comes from the data on ${ }^{13} \mathrm{C}$ uptake into individual PLFAs, which were affected by a marginally significant $(P=0.061)$ treatment $\times$ month interaction. However, this interpretation is not supported by our PCR-DGGE analyses (Supplementary Figure S4) and is further refuted by the statistically consistent mineralization rates in May and October. It is possible that treatment effects on carbon mineralization and hence BGE were attributable to a differential archaeal response, although their negligible contributions $(<<5 \%)$ to the prokaryotic communities of surficial sediments (Sahm and Berninger, 1998; Vetriani et al., 1999; Lipp et al., 2008) indicates that this is unlikely. Furthermore, we found no evidence to suggest that the archaeal community composition changed in response to our different experimental treatments (Supplementary Figure S4). We therefore suggest a more parsimonious explanation is that differences in carbon quality between the treatments caused an uncoupling of bacterial catabolic and anabolic processes. Bacteria solubilize and catabolize available substrates at maximal rates, independent of their specific requirements (del Giorgio and Cole, 1998; Vetter et al., 1998). This results in reduced BGE when growth is constrained by factors such as temperature and nutrient supply, rather than organic carbon (energy) (del Giorgio and Cole, 1998). Previous studies have demonstrated that the growth of barophilic bacteria isolated from depths $\geqslant 3584 \mathrm{~m}$ is affected by temperature, pressure and substrate supply (Yayanos, 1986; Wirsen and Molyneaux, 1999; Eloe et al., 2011), with the production of new biomass declining rapidly as temperatures drop below $0{ }^{\circ} \mathrm{C}$ (Yayanos, 1986). Experiments conducted on barotolerant microbial communities from much shallower $(\leqslant 2003 \mathrm{~m})$, Arctic sediments have demonstrated that the effects of labile substrate supply on bacterial catabolic activities predominate over those of temperature, salinity and pressure (MeyerReil and Köster, 1992; Arnosti et al., 1998). We therefore contend that the counterintuitive effect of resource quality on BGE demonstrates that bacterial community respiration in our sub-zero experiments was substrate limited, whereas their PLFA biosynthesis (growth) was not. This interpretation may also explain why deep-sea benthic BGE apparently decreases when offered increased quantities of organic substrates (Bühring et al., 2006).

We propose that bacterial biosynthetic pathways in our near-freezing experiments were temperature limited, a mechanism frequently invoked to explain the production of bacterioplankton communities outside of seasonal temperature maxima (Shiah and Ducklow, 1994; Apple et al., 2006). The notion that respiration and growth were substrate and temperature limited, respectively, is consistent with the understanding that these factors influence the growth efficiencies and production of heterotrophic bacteria to differing extents (Arnosti et al., 1998; Pomeroy and Wiebe, 2001; Apple et al., 2006). This, in turn, reflects that respiration and growth are the summation of numerous, discrete enzymatic pathways, all of which respond differently to temperature (Clarke, 1991). Similar, carbon-quality effects at a low temperature have previously been demonstrated in a study examining microbial activity in the accreted ice of Lake Vostok: melt water samples enriched with qualitatively different carbon substrates and incubated at $1^{\circ} \mathrm{C}$ revealed clear substrate-identity effects on mineralization but not growth; substrate effects on growth were, however, apparent when incubated at $23^{\circ} \mathrm{C}$ (Karl et al., 1999). The recent observation that the effects of food stoichiometry on growth rate diminish as an organism approaches its lower thermal limit (Persson et al., 2011) lends further support to our data interpretation. Nevertheless, considering the similar bulk elemental composition of the diatoms and faecal pellets $(\mathrm{C} / \mathrm{N}$ ratio $=6.3 \pm 0.2$ and $8.2 \pm 0.1$ by atoms, respectively), we cannot conclusively exclude the possibility of nitrogen-limited bacterial growth (Boetius and Lochte, 1996) in both treatments and stoichiometric regulation of the excess, labile organic carbon in the diatom treatment via futile metabolic cycles (del Giorgio and Cole, 1998). It is unlikely that that enhanced bacterial growth was apparent but not discernable owing to rapid protistan grazing (Boetius and Lochte, 1996), although we cannot dismiss losses due to viral lysis (Danovaro et al., 2008).

We have shown that the residence time of organic carbon at the deep seabed is profoundly affected by the lability of the vector within which it is delivered, and assert that the respiration and growth of the resident microbial communities are limited by the supply of labile substrates and temperature, respectively. It follows that future climate-driven changes in the composition of marine phytoplankton communities (Edwards and Richardson, 2004), and hence the biochemical makeup of exported organic matter, have the potential to impact upon the balance between carbon mineralization and burial in the largest habitat on Earth. A more complete understanding of the physiology and ecology of deep-sea organisms is required before the processes regulating their growth, and ultimately the fate of elements in this environment, can be fully appreciated.

\section{Acknowledgements}

This research was funded by the Leverhulme Trust (F/00152/T) and supported by NERC's Life Sciences Mass 
Spectrometry Facility (EK116-11-07). DJM is currently funded by NERC (NE/G014744/1). BT received funding from the Rural and Environment Science and Analytical Services Division (RESAS) of the Scottish Government. We gratefully acknowledge $G$ Slesser and all those that sailed onboard FRV Scotia (Marine Scotland Science). Thanks to E Lines for field assistance, M Machairopoulou for macrofauna identification, M Procee, G Martin and PJ Martin for logistical support, E Gontikaki and A Douglas for thoughtful discussions, J Newton for the elemental and IRMS analysis of bulk sediment samples and various colleagues and three anonymous reviewers for their constructive input on an earlier draft of this manuscript. DJM thanks TR Anderson for his continued mentorship.

\section{Author contributions}

DJM designed and performed the research; DJM and BT analysed the samples; DJM and AFZ analysed the data; DJM wrote the paper and all co-authors commented; SH, DJM and UFMW co-authored the original grant.

\section{References}

Andersson JH, Woulds C, Schwartz M, Cowie GL, Levin LA, Soetaert K et al. (2008). Short-term fate of phytodetritus in sediments across the Arabian Sea oxygen minimum zone. Biogeosciences 5: 43-53.

Apple JK, del Giorgio PA, Kemp WM. (2006). Temperature regulation of bacterial production, respiration and growth efficiency in a temperate salt-marsh estuary. Aquat Microb Ecol 43: 243-254.

Arnosti C, Jørgensen BB, Sagemann J, Thamdrup B. (1998). Temperature dependence of microbial degradation of organic matter in marine sediments: polysaccharide hydrolysis, oxygen consumption, and sulphate reduction. Mar Ecol Prog Ser 165: 59-70.

Bathmann UV, Noji TT, Voss M, Peinert R. (1987). Copepod fecal pellets: abundance, sedimentation and content at a permanent station in the Norwegian Sea in May/June 1986. Mar Ecol Prog Ser 38: 45-51.

Billett DSM, Lampitt RS, Rice AL, Mantoura RFC. (1983). Seasonal sedimentation of phytoplankton to the deepsea benthos. Nature 302: 520-522.

Boetius A, Lochte K. (1996). Effect of organic enrichments on hydrolytic potentials and growth of bacteria in deep-sea sediments. Mar Ecol Prog Ser 140: 239-250.

Boschker HTS, Middelburg JJ. (2002). Stable isotopes and biomarkers in microbial ecology. FEMS Microb Ecol 40: 85-95.

Brinch-Iversen J, King GM. (1990). Effects of substrate concentration, growth state, and oxygen availability on relationships among bacterial carbon, nitrogen and phosphorus content. FEMS Microbiol Lett 74: 345-355.

Bühring SI, Lampadariou N, Moodley L, Tselepides A, Witte U. (2006). Benthic microbial and wholecommunity responses to different amounts of ${ }^{13} \mathrm{C}$-enriched algae: in situ experiments in the deep Cretan Sea (Eastern Mediterranean). Limnol Oceanogr 54: 157-165.

Burdige DJ. (2007). Preservation of organic matter in marine sediments: controls, mechanisms and an imbalance in sediment organic carbon budgets? Chem Rev 107: 467-485.

Clarke A. (1991). What is cold adaptation and how should we measure it? Amer Zool 31: 81-92.

Cowie GL, Hedges JI. (1996). Digestion and alteration of the biochemical constituents of a diatom (Thalassiosira weissflogii) ingested by an herbivorous zooplankton (Calanus pacificus). Limnol Oceanogr 41: $581-594$.

Danovaro R, Dell'Anno A, Cordinaldesi C, Magagnini M, Noble R, Tamburini C et al. (2008). Major viral impact on the functioning of benthic deep-sea ecosystems. Nature 454: 1084-1087.

del Giorgio PA, Cole JJ. (1998). Bacterial growth efficiency in natural aquatic systems. Annu Rev Ecol Syst 29: 503-541.

Edwards M, Richardson AJ. (2004). Impact of climate change on marine pelagic phenology and trophic mismatch. Nature 430: 881-884.

Eloe EA, Malfatti F, Gutierrez J, Hardy K, Schmidt WE, Pogliano $\mathrm{K}$ et al. (2011). Isolation and characterization of a psychropiezophilic alphaproteobacterium. App Env Microbiol 77: 8145-8153.

Gontikaki E, Mayor DJ, Narayanaswamy BE, Witte W. (2011a). Feeding strategies of deep-sea sub-Arctic macrofauna of the Faroe-Shetland Channel: combining natural stable isotopes and enrichment techniques. Deep-Sea Res I 58: 160-172.

Gontikaki E, Mayor DJ, Thornton B, Black K, Witte U. (2011b). Processing of ${ }^{13} \mathrm{C}$-labelled diatoms by a bathyal community at sub-zero temperatures. Mar Ecol Prog Ser 421: 39-50.

Gooday AJ, Turley CM. (1990). Responses by benthic organisms to inputs of organic material to the ocean floor: a review. Phil Trans $R$ Soc Lond A 331: 119-138.

Graf G. (1989). Benthic-pelagic coupling in a deep-sea benthic community. Nature 341: 437-439.

Hensen C, Zabel M, Schulz HN. (2006). Benthic cycling of oxygen, nitrogen and phosphorus. In Schulz HD, Zabel M (eds). Marine Geochemistry. Springer-Verlag: Berlin, pp 207-240.

Jahnke RA. (1996). The global ocean flux of particulate organic carbon: areal distribution and magnitude. Glob Biogeochem Cy 10: 71-88.

Karl DM, Bird DF, Björkman K, Houlihan T, Shacklford R, Tupas L. (1999). Microorganisms in the accreted ice of Lake Vostok, Antarctica. Science 286: 2144-2147.

Lampitt RS, Achterberg EP, Anderson TR, Hughes JA, Iglesias-Rodriguez MD, Kelly-Gerreyn BA et al. (2008). Ocean fertilization: a potential means of geoengineering? Phil Trans Roy Soc A 366: 3919-3945.

Lipp JS, Morono Y, Inagaki F, Hinrichs K-U. (2008). Significant contribution of archaea to extant biomass in marine subsurface sediments. Nature 454: 991-994.

Mayor DJ, Cook K, Thornton B, Walsham P, Witte UFM, Zuur AF et al. (2011). Absorption efficiencies and basal turnover of $\mathrm{C}, \mathrm{N}$ and fatty acids in a marine Calanoid copepod. Funct Ecol 25: 509-518.

Meyer-Reil L-A, Köster M. (1992). Microbial life in pelagic sediments: the impact of environmental parameters on enzymatic degradation of organic material. Mar Ecol Prog Ser 81: 65-72.

Moodley L, Middelburg JJ, Soetaert K, Boschker HTS, Herman PMJ, Heip CHR. (2005). Similar rapid response to phytodetritus deposition in shallow and deep-sea sediments. J Mar Res 63: 457-469. 
Muyzer G, de Waal EC, Uitterlinden AG. (1993). Profiling of complex microbial populations by denaturing gradient gel electrophoresis analysis of polymerase chain reaction-amplified genes encoding for $16 \mathrm{~S}$ rRNA. Appl Environ Microbiol 59: 695-700.

Nicol GW, Campbell CD, Chapman SJ, Prosser JI. (2007). Afforestation of moorland leads to changes in crenarchaeal community structure. FEMS Microbiol Ecol 60: $51-59$.

Persson J, Wojewodzic MW, Hessen DO, Andersen T. (2011). Increased risk of phosphorus limitation at higher temperatures for Daphnia magma. Oecologia 165: $123-129$.

Pomeroy LR, Wiebe WJ. (2001). Temperature and substrates as interactive limiting factors for marine heterotrophic bacteria. Aquat Microb Ecol 23: 187-204.

R Development Core Team. (2010). R: A Language and Environment for Statistical Computing. R Foundation for Statistical Computing, Vienna. Available at: http://www.R-project.org.

Ruhl HA, Ellena JA, Smith Jr KL. (2008). Connections between climate, food limitation, and carbon cycling in abyssal sediment communities. Proc Natl Acad Sci USA 105: 17006-17011.

Sahm K, Berninger U-G. (1998). Abundance, vertical distribution, and community structure of benthic prokaryotes from permanently cold marine sediments (Svalbard, Arctic Ocean). Mar Ecol Prog Ser 165: 71-80.

Schlüter M, Sauter EJ, Schäfer A, Ritzrau W. (2000). Spatial budget of organic carbon flux to the seafloor of the northern North Atlantic $\left(60^{\circ} \mathrm{N}-80^{\circ} \mathrm{N}\right)$. Glob Biogeochem Cy 14: 329-340.

Shiah F-K, Ducklow HW. (1994). Temperature and substrate regulation of bacterial abundance, production and specific growth rate in Chesapeake Bay, USA. Mar Ecol Prog Ser 103: 297-308.

Smith CR, Berelson W, Demaster DJ, Dobbs FC, Hammond D, Hoover DJ et al. (1997). Latitudinal variations in benthic processes in the abyssal equatorial Pacific:control by biogenic particle flux. Deep-Sea Res II 44: 2295-2317.

Thornton B, Zhang Z, Mayes RW, Högberg MN, Midwood AJ. (2011). Can gas chromatography combustion isotope ratio mass spectrometry be used to quantify organic compound abundance? Rapid Commun Mass Sp 25: 2433-2438.

Van Nugteren P, Herman PMJ, Moodley L, Middelburg JJ, Vos M, Heip CHR. (2009). Spatial distribution of detrital resources determines the outcome of competition between bacteria and a facultative detritivorous worm. Limnol Oceanogr 54: 1413-1419.

Vetriani C, Jannasch HW, MacGreggor BJ, Stahl DA, Reysenbach A-L. (1999). Population structure and phylogenetic characterization of marine benthic archaea in deep-sea sediments. App Env Microbiol 65: $4375-4384$.

Vetter YA, Deming JW, Jumars PA, Krieger-Brockett BB. (1998). A predictive model of bacterial foraging by means of freely released extracellular enzymes. Microb Ecol 36: 75-92.

White DC, Davis WM, Nickels JS, King JD, Bobbie RJ. (1979). Determination of the sedimentary microbial biomass by extractible lipid phosphate. Oecologia 40: 51-62.

Wirsen CO, Molyneaux SJ. (1999). A study of deep-sea natural microbial populations and barophilic pure cultures using a high-pressure chemostat. App Env Microbiol 65: 5314-5321.

Witte U, Wenzhöfer F, Sommer S, Boetius A, Heinz P, Aberle $\mathrm{N}$ et al. (2003). In situ experimental evidence of the fate of a phytodetritus pulse at the abyssal sea floor. Nature 424: 763-766.

Wolff GA, Billett DSM, Bett BJ, Holtvoeth J, FitzGeorgeBalfour T, Fisher EH et al. (2011). The effects of natural iron fertilisation on deep-sea ecology: the Crozet Plateau, Southern Indian Ocean. PLoS One 6: e20697.

Woulds C, Cowie GL, Levin LA, Andersson JH, Middelburg JJ, Vandewiele S et al. (2007). Oxygen as a control on seafloor biological communities and their roles in sedimentary carbon cycling. Limnol Oceanorg 52: 1698-1709.

Yayanos AA. (1986). Evolutinoal and ecological implications of the properties of deep-sea barophilic bacteria. Proc Natl Acad Sci USA 83: 9542-9546.

Zuur AF, Ieno EN, Walker NJ, Saveliev AA, Smith GM. (2009). Mixed-Effects Models and Extensions in Ecology with $R$. Springer: New York.

Zuur AF, Ieno EN, Elphick CS. (2010). A protocol for data exploration to avoid common statistical problems. Method Ecol Evolut 1: 3-14.

Supplementary Information accompanies the paper on The ISME Journal website (http://www.nature.com/ismej) 